Chicago, Municipal Voters' League.

Cleveland, Civic League of Cleveland.

Denver, Civic League of Denver.

Illinois, Legislative Voters' League of the State of Illinois.

Milwaukee, Municipal Voters' League.

Minneapolis, Voters' League.

New York City, Citizens' Union of New York.

Pittsburgh, Voters' League.

Portland, Ore., Municipal Association.

St. Louis, Municipal Voters' League.

Seattle, Municipal League of Seattle.

Wheeling, W. Va., Municipal Voters' League.

\title{
MOTOR BUS DEVELOPMENTS AND POSSIBILITIES
}

\section{BY WILLIAM RICHARD LITTLETON \\ University of Pennsylvania}

$\cap \mathrm{H}$

$\mathrm{HE}$ motor bus is the natural born enemy of the street railway corporation. It is an enemy which is. growing in strength and size each year as we see more clearly its many advantages and possibilities. As the motor bus in London is replacing the horse-drawn vehicles, so will the motor bus in this country replace the street railroad by its greater efficiency, or at least cause it to become a lesser factor in the great and ever-increasing problem of municipal transportation.

One of the griat advantages of the motor bus is that each is an independent unit. The cost of operation and maintenance is far below that of the trolley car. There need be no central power plant, and the expensive track and overhead wires that have for years disfigured our streets are entirely eliminated. A breakdown or accident to one bus does not interfere with the others, whereas a broken wire or derailed car will tie up the street car line for hours. Besides the decreased expense of installation, bus lines can be rerouted at the discretion of the city authorities to suit the convenience of the public. Experimenting with new routes into the suburbs or within the city can be readily tried with little or no expense. It can bring about the rapid development of a sparsely populated section because its mobility enables it to run anywhere. If the new route does not pay, there is no great loss incurred through the laying of track and wire.

The bus can maintain a slightly higher average rate of speed than a tramway. It can start and stop more quickly and the establishment of an express service makes increased rapid transit a certainty by having a certain number of buses on the route stop only at designated points.

New York City has been one of the pioneers in this country in adopting the motor bus as a means of transportation. In a recent report by the bureau of franchises to the franchise committee, on an application now 
pending before the board of estimate and apportionment, made by four companies for the right to operate motor buses in the Borough of Manhattan, it was set forth that the aggregate length of all routes covered by the

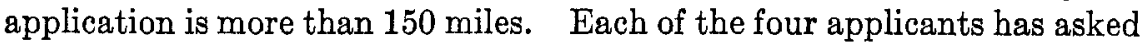
for routes connecting the residential sections on the east and west sides of Central Park with what may be termed the hotel, theatre, wholesale and retail districts, containing also the terminal railway stations of the Pennsylvania and Long Island railroads at 33d Street and Seventh Avenue, and the New York Central and New York, New Haven and Hartford railroads at $42 \mathrm{~d}$ Street. The routes which have been selected on the upper west side of the borough in addition to the west side route, are upon thoroughfares in which there are practically no street surface railways, and are designed to give special local service, as well as service in connecting the east and west side lines extending into the business district.

It is apparent that the motor bus companies are willing to give good service and the territory mentioned is completely covered. Nevertheless, in an effort to lay out a comprehensive system, the applications have been almost wholly disregarded because many more routes have been applied for than are necessary to form a comprehensive system. The experience which the city has had with the operation of motor buses has been so limited that it is believed the city should be very conservative in the number of routes which it authorizes in the beginning.

Many of our western cities are at present giving the auto bus serious and careful consideration. In Los Angeles, it has been estimated that , forty thousand nickels which formerly were given daily to the street railways in payment for transporation, now go to the men who operate the five cent fare automobiles.

Some drivers figure on the wear and tear on the car, others merely consider the cost of gasoline. These latter say that a cent and three quarters or two cents a mile will cover the cost of operation, while the former add a cent for deterioration of their machines. These figures are for five passenger cars, the kind most commonly used.

One of the pioneers in auto transportation in Los Angeles has estimated carefully on the cost of running his five passenger car per day. He makes 18 round trips daily, averaging 50 cents a round trip and thus taking in $\$ 9$ every day. All this is not net to him, however, as he figures the wear and tear on his automobile and the cost of operation at 3 cents a mile and the round trip is a matter of eight miles. But even then there is a profit of $\$ 4.68$ a day.

Besides several double-decked bus lines in Los Angeles, there are some eighty automobiles on a single route; while other lines increase the number of machines so used to between 250 and 300 ; and the prediction is made that when the men thus engaged perfect their organization and establish new routes, that fully twice as many machines will begin service.

The strongest argument set forth by the people is that they get home 
more quickly; and with the public taking that view, and the owners of automobiles willing to carry them for five cents, the prediction is that in time the auto buses will entirely supersede the street cars, not only of Los Angeles but in all large cities throughout the world.

It is the opinion of City Attorney Stephens of Los Angeles that the council could not compel the auto bus people to take out franchises; but he expressed the opinion that these concerns could be regulated. The question as to what extent the bus lines can be regulated is before the utilities board and the council. Compelling operators of bus lines to file indemnity bonds is one method sought for regulation. This has been objected to on the ground that street car lines have not been compelled to file indemnity bonds. Another method suggested for regulation was that of requiring them to run on regularly stated routes and on a definite schedule.

Notwithstanding the fact that the commissioners of Pasadena, Cal., have passed restrictive ordinances on the operation of motor bus lines, the taxpayers protective association placed itself on record as favoring a new motor bus ordinance. A. C. Ong on behalf of the bus people declared that if the citizens of Pasadena were fully aware of the effect of this sweeping ordinance on the interests of every citizen of Pasadena, that 90 per cent of the taxpayers and residents would gladly petition the rescinding of the drastic measures taken. He said that auto bus drivers should be encouraged, and that an ordinance should be enacted that will extend further advantages and accommodations to the residents of the city.

Ira F. Thompson, attorney for the Pacific Motor Coach Company, which had been denied the privilege of running over one section of the route between Pasadena and Los Angeles, said that it was all done in the interests of the Southern Pacific, who own and control the electric lines. It is evident from this that the future success of the motor bus cannot be accomplished without a long, hard fight, a fight against wealth, wellestablished interests, whose power to control municipal legislation is practically unlimited in many instances.

Chicago has been quite successful in the establishment of an auto-bus line. The Chicago Automobile Transportation Company has made application for permission to run a line of double-decked buses, each with a capacity of thirty-five passengers, the fare being ten cents. The service will include trips through the park system and will carry passengers from "the loop" to their houses in a fourth less time than is taken by the street cars.

In looking for past experience and actual costs of operation, it is necessary to refer to the cities of Europe. There the auto bus has been running longer and has been more extensively used than in any of our American cities. City ownership there has already begun. Subject to the approval of Parliament, Birmingham, England, proposes to purchase some 30 omnibuses and plant for $\$ 165,000$. This purchase will give the city the monopoly of the motor omnibus service within its boundaries under the 
agreement that, while through omnibuses from outside points may be run by the original company into the city and by the city into the country, neither is to pick up any but through passengers within the limits of the other's activities.

The cost per mile ranges from $13.374 \mathrm{~d}$. to as low as $4.83 \mathrm{~d}$. In nearly every case the buses operate in different districts where the roads are not of the best. In showing exact calculations per car mile in different cities of England we have:

\begin{tabular}{|c|c|}
\hline Birmingham & $9.288 \mathrm{~d}$. \\
\hline Oldham..... & $13.374 \mathrm{~d}$. \\
\hline Rotherham... & $6.78 \mathrm{~d}$. \\
\hline Sheffield. & $6.675 \mathrm{~d}$. \\
\hline Warringdon. . & 7.63 \\
\hline Wolverhampton & 8.28 \\
\hline
\end{tabular}

As showing the extent to which motor omnibuses are being called into municipal service, it is interesting to note that nearly fifty local authorities now operate, or have power to operate, these vehicles.

In making a fair comparison between the motor bus and the street car, we must take into consideration the fact that the bus travels over a municipally-owned highway, wearing down and depreciating the road, while the street car furnishes its own surface and pays for its depreciation. Nevertheless there is nothing to indicate that the wood-paved roads, as a whole, were costing more to maintain. It was stated definitely that in Westminster, England, wood-paved roads have cost less to maintain and that this year the cost was less than it was eight years ago. In taking a certain road the car mileage of the buses was calculated and allowing that the levy for this form of traffic would be $\frac{3}{8} \mathrm{~d}$. per car mile, $£ 4000$ would have been received, whereas the total cost of maintenance was only $£ 2800$. It was also clearly stated that the effect of the motor bus was no different from that of any other form of traffic, provided the road was suitable and was kept in a reasonable state of repair; the motor bus was reasonably proportioned in the weight of the load on the wheel in contact with the road surface and that therefore, so far as ordinary wear and tear were concerned, the motor bus did no more harm than the standard type of motor car; that the motor car travelling at high speed did as much damage when the road was in a bad state as the heavier vehicle travelling at the slower speed usual with such vehicles. It may be taken that wherever there is a road on which more than 1,000 buses run per day, the amount collected from a levy on those buses will more than cover the total cost of the maintenance of the roadway, even if provided with the most expensive pavement. ${ }^{1}$

${ }^{1}$ Motor buses in England have unexpectedly been of national as well as local aid. It is stated that several thousands of London motor buses and drivers have gone to the front and rendered invaluable aid in transport work. Practically the whole of the single decked motor buses have been converted into motor ambulances. 
Taking into consideration the case of the street car, the rail is at a fixed level and does not wear equally with the other material forming the road structure; the vehicles using the side of the road track each other; in other words, the traffic is concentrated, and therefore the wear is very severe. Wood paving, when it forms the whole surface of a road without car rails, may be allowed to wear away to the extent of an average of $2 \frac{1}{4}$ inches, but it would be impossible to allow a roadway 10 feet wide to wear $2 \frac{1}{4}$ inches; if the wear shows more than $1 \frac{1}{4}$ inches, the paving becomes so bad that it has to be removed and renewed. Therefore, if the road is in regard to half its width taken up by car rails, the remaining half costs nearly twice as much to maintain as the whole road did formerly - i. e. before the car rails were laid, and the relief to the ratepayer is of little or no account.

In summing up the facts it is plainly apparent that the many advantages of auto bus transportation give a municipality:

(1) Quicker and easier service.

(2) An increase of revenues.

(3) An elimination of excessive noise.

(4) A better chance for expansion and increased suburban and interurban service.

(5) An opportunity for increasing the beauty of the city by the elimination of car tracks and overhead wires, and for an appreciation of street width. ${ }^{1}$

${ }^{1}$ Concerning the use of motor buses, the Municipal Journal of July 24, 1913, editorially said:

The adopting of motor buses by Huntington, Ind., in place of street cars running on rails, raises the question whether the time has come or is coming when this can be adopted as a more or less general practice by small cities and villages. With more perfect roads and improved motors it is certainly more practicable than it was ten years ago.

There are several arguments in favor of buses as compared with cars running on tracks. Some of these are mentioned in the article, but there are others, among them the following: No special area of street is turned over to a private corporation. The smoothness and life of the roadway pavement are not lessened by the presence of rails throughout its length. No poles or wires are necessary (the underground trolley is too expensive a construction for small communities). The noise of steel tire on steel rail is avoided-a most serious objection on residence streets. It would not be possible for one or two property owners to prevent the operation over a given route by refusing their consent to laying track in front of their properties, as is so often done where trolley lines are proposed and even needed. A mistake in judgment in locating a route is by no means irreparable $-a$ change requires only the consent of the franchise granting power. In fact, the route might be changed from hour to hour during each day, as the users of the buses desired to go to or from the factories, the shopping district, the amusement center, etc. A temporary obstruction, such as repairing a road, need occasion little inconvenience to buses other than making a detour of a block.

A serious question is whether the cost of power and of maintaining heavy buses traveling over roads never as smooth as rails, especially when the power is in the form of storage batteries as compared with a central power house, can be kept low enough to make the enterprise a paying one with 5-cent fares. 